\title{
Influence of Different Metals Back Surface Field on BSF Silicon Solar Cell Performance Deposited by Thermal Evaporation Method
}

\author{
Rashed Al Amin ${ }^{1}$, M. F. Pervez ${ }^{2, *}$, M. N. H. Mia ${ }^{2}$, M. Khalid Hossain², S. M. Rana ${ }^{2}$, \\ N. A. Khan ${ }^{3}$, M. A. S. Haque ${ }^{2}$, H. K. Ghosh ${ }^{2}$, M. Hoq ${ }^{2}$ \\ ${ }^{1}$ Mymensingh Engineering College, University of Dhaka, Bangladesh \\ ${ }^{2}$ Institute of Electronics, Atomic Energy Research Establishment, Bangladesh \\ ${ }^{3}$ Solar Energy Research Institute (SERI), National University of Malaysia, Malaysia
}

Copyright $\mathrm{C} 2017$ by authors, all rights reserved. Authors agree that this article remains permanently open access under the terms of the Creative Commons Attribution License 4.0 International License

\begin{abstract}
This paper presents comparison of thermal evaporation method based passivation and BSF formation with different materials ( $\mathrm{Au}, \mathrm{Al}$, and $\mathrm{Cu}$ ). Silicon solar cells with different rear surface contact using these materials were fabricated. A comprehensive comparison of the samples have been carried out to find better back surface contact regarding the efficiency by investigating I-V characteristics, fill factor, external quantum efficiency and carrier diffusion length and lifetime, etc. Experimental data revealed that $\mathrm{Cu}$ based back surface contact has maximum output efficiency of about $13.73 \%$, whereas Au shows maximum external quantum efficiency of about $86 \%$. Moreover, use of $\mathrm{Al}$ shows the maximum carrier diffusion length $97.2 \mu \mathrm{m}$ and highest carrier lifetime of $3.5 \mu$ s with overall cell efficiency of $12.90 \%$ indicating that $\mathrm{Al}$ is a promising material for back contact for $\mathrm{n}^{+}-\mathrm{p}-\mathrm{p}^{+}$back surface field silicon solar cell.
\end{abstract}

Keywords Back Surface Field (BSF), External Quantum Efficiency, Gold, Aluminum, Copper

\section{Introduction}

Commercial wafer based silicon solar cell production involves the use of expensive aluminum (Al) paste as screen printed back contact that contributes towards a moderate level of Back Surface Field (BSF). As BSF plays a significant role in improving the cell performance as well as minimizing the cost of production, therefore introducing new methods and materials for BSF is still under consideration.

Crystalline silicon photovoltaic (PV) cells are still the most widely used technology for commercial solar cell production $[1,3]$. Increasing the efficiency of solar cells with lower fabrication cost is a major challenge in photovoltaic research. However, the efficiency of a solar cell is restricted by the main three loss mechanisms: absorption loss, electrical loss and minority carrier surface recombination loss [3-5]. All these three types of losses are associated with rare surface contact (back contact) where metals are commonly used to form metal-semiconductor contact. In addition to that, metallization cost is the second most expensive step in the photovoltaic cell production [6]. Moreover, back contact can act as a reflector which plays a crucial role in improving light-trapping properties and improving the cell efficiency. At the same time, improved back reflectivity reduces photon absorption that leads to higher quantum efficiency. Furthermore, less resistive ohmic back contact results in less joule heating enhancing electrical efficiency [3] [7]. Thus, materials used in back contact and methodology of back contact formation is an important factor for improving the cell efficiency and reducing the production cost. 


\section{Annual production by cell technology type}

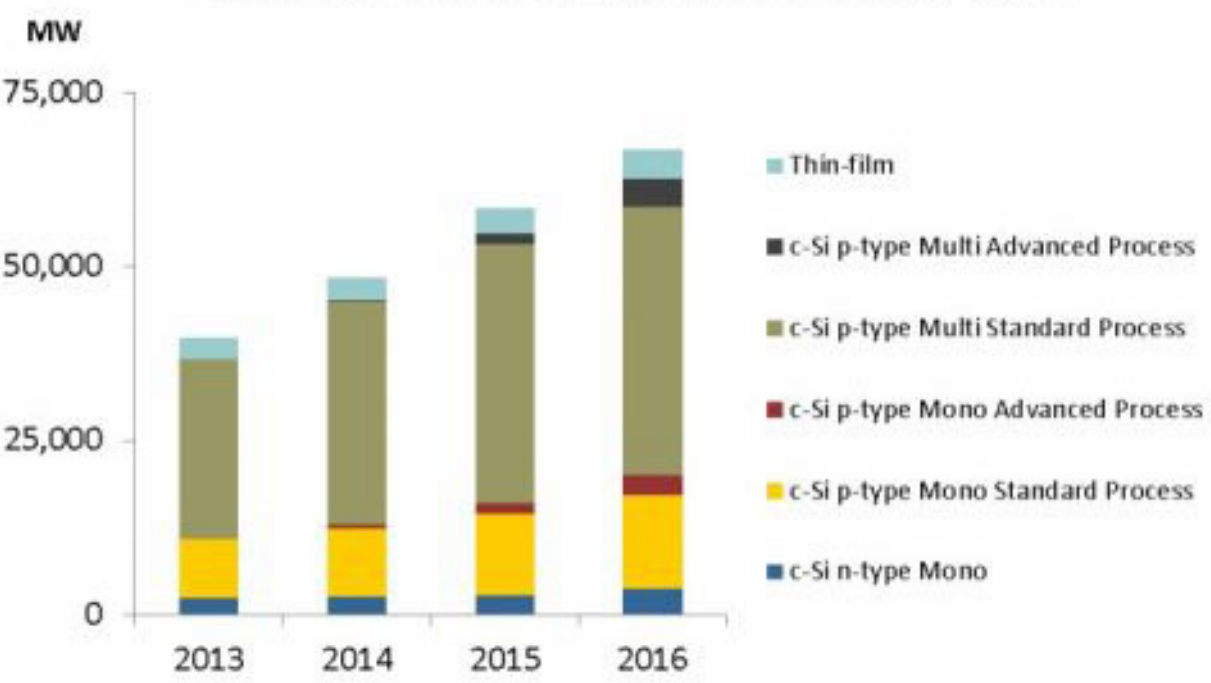

Figure 1. Different solar cell fabrication technology annual production [1]

\section{CONVENTIONAL CELL}

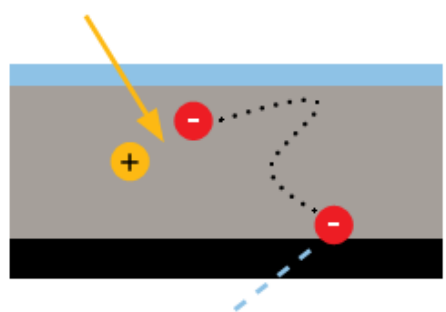

If an electron reaches the back surface, it is frequently captured and can no longer contribute.

\section{CELL WITH BACKSIDE PASSIVATION}

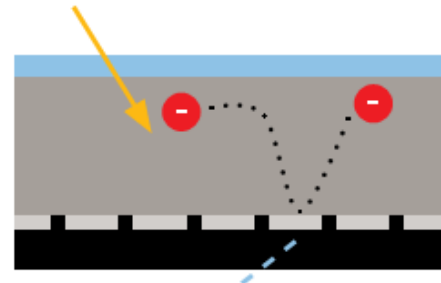

Backside passivation stops the electron from being captured, and gives it a 'second chance' to reach the emitter and contribute to the current.
Dielectric layer

- - Small metal contacts

Figure 2. Back-side passivation to reduce recombination [2]

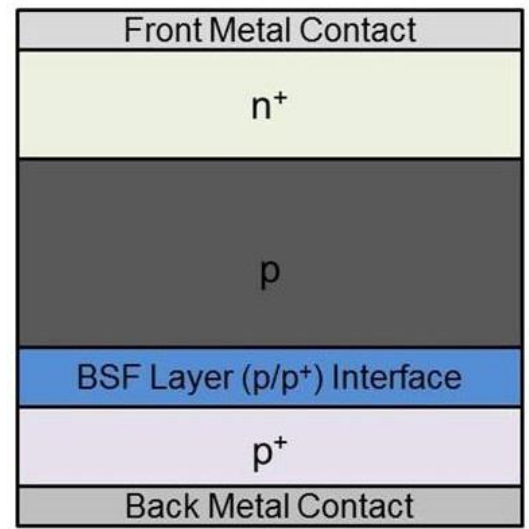

(a)

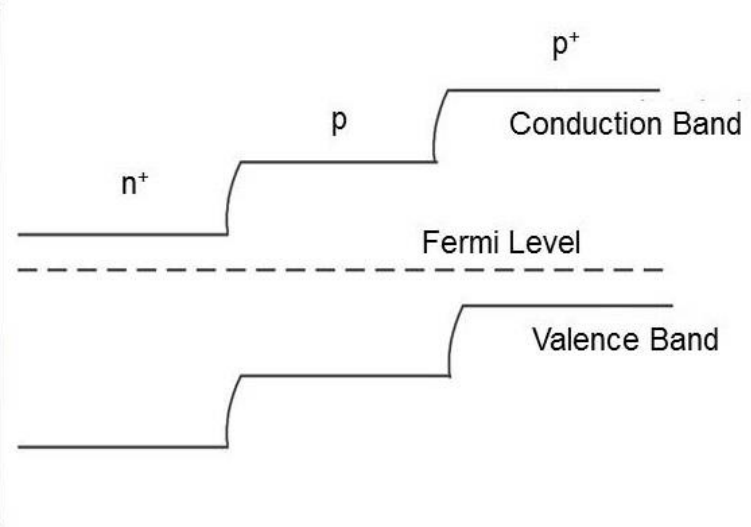

(b)

Figure 3. (a) $n^{+}-p-p^{+}$BSF solar cell schematic diagram (b) band diagram of an $n^{+}-p-p^{+}$solar cell 
One of the major factors of degradation of cell performance is minority carrier surface recombination, lowering open circuit voltage $\left(\mathrm{V}_{\mathrm{OC}}\right)$ and short circuit current $\left(\mathrm{I}_{\mathrm{SC}}\right)$ of the cell [4]. To minimize the surface recombination loss at the back-surface of photovoltaic cells, instead of primarily invented $n^{+} p$ solar cell, $n^{+}-p-p^{+}$and $p^{+}-p-n^{+}$type solar cell also known as low-high or back surface field (BSF) solar cell has been already introduced in industrial production [7-11]. The highly doped $\mathrm{p}^{+}$region with the lightly doped p-type semiconductor result in an electric field commonly known as Back Surface Field (BSF) [9]. BSF at $\mathrm{p}^{+} / \mathrm{p}$ region repeals the minority carrier to enter the back surface reducing surface recombination rate hence increasing minority carrier diffusion length and carrier collection efficiency [5][7][12]. Fig-3 shows the, $\mathrm{n}^{+}-\mathrm{p}-\mathrm{p}^{+}$solar cell schematic diagram.

Silver (Ag) and aluminum (Al) pastes in screen print technique is still the main metallization technology for the PV-industry to form the back contact [13] [14]. But in this method, a large amount of expensive paste is wasted with moderate passivation reducing surface reduction velocity [15-16]. Hence, several types of materials, methodology and geometrical structure have been introduced to form the back surface in order to improve the cell efficiency by researchers over the years [20-23]. In recent years, another potential cheaper contact-forming technique, deposition by evaporation, has been attempted that can replace fired silver/aluminum paste screen printed deposition forming the required thickness of back surface contact within very short time having advantages of good ohmic contact [6][17][24-25]. However, the impact of other materials as BSF with different metals having different work-functions by thermal evaporation method is yet to be studied thoroughly.

In this research, at first a single crystal silicon solar cell fabricated on p-type wafer without back contact is cut down to produce a number of identical small samples. Afterwards, aluminum, copper, and gold were deposited on the back surface by thermal evaporation method on the different samples. Afterwards, the samples were sent to Rapid Thermal Annealing Process (RTP) that leads to the formation of highly doped $\mathrm{p}^{+}$region establishing BSF [18]. Next, several experiments had been conducted including incident photon-to-current efficiency (IPCE), surface photo voltage (SPV) measurement, I-V characteristics and fill factor to compare the impact of different evaporation based back contact materials on silicon solar cells. Finally, electrical efficiency, external quantum efficiency as well as minority carrier diffusion length and lifetime, and fill factor are estimated from the experimental data to compare with one another in search of better back contact.

\section{Methodology}

P-type Cz-Si wafers with base resistivity of $1-2 \Omega \mathrm{cm}$ were used in this experiment. At first, saw-damage removal and surface texturing were carried out in order to increase the optical absorption of the incident light [26]. Appling alkaline solutions $(\mathrm{KOH})$, anisotropic texturing, a process of formation of random pyramids on the silicon surface, was created [27]. Afterwards, the wafers were cut down into pieces of $2 \times 2 \mathrm{~cm}$ before metallization of front and back surface to make different samples. Then, thermal evaporation process was applied at an air pressure of $1.6 \times 10^{-5}$ torr by a thermal evaporator (Min-coater, Tectra, Germany). Initially, the front surface was deposited by silver for all the samples. Then all the samples back surface were deposited by different metals $(\mathrm{Au}, \mathrm{Cu}$, and $\mathrm{Al})$. Next, rapid thermal annealing process, where samples pass through a moving belt was applied with the temperature profile of $500^{\circ} \mathrm{C}, 600^{\circ} \mathrm{C}$, and $800^{\circ} \mathrm{C}$, respectively.

The characterization of the individual samples were performed by K3100EQX Spectral IPCE Measurement System, from which the external quantum efficiency (EQE) was measured by incident photon-to-current efficiency (IPCE) method in the spectral range of 360-1100 nm wavelength. Followed by LIV measurement to measure the cell efficiency and fill factor using a standard AM 1.5 calibrated DC LIV Solar Cell Characterization System. Finally, the surface photo voltage (SPV) of the samples had been measured for the wavelength ranging from $400 \mathrm{~nm}$ to $1000 \mathrm{~nm}$. Minority carrier diffusion length had been estimated by Goodman (1961) method; and then carrier lifetime measurement carried out by the formula $L_{n}=$ $\sqrt{D} \tau_{n}$; where $L_{n}$, the diffusion length for electron, $D$ is the diffusivity, and $\tau_{\mathrm{n}}$ is the minority carrier lifetime [19].

\section{Results and Discussion}

The external quantum efficiency measurement is done to measure the photon to electron conversion efficiency with the different BSF materials used. The fig.-4 shows the EQE measurement of silicon solar cell with different BSF layers deposited by thermal evaporation process. Among the samples, the EQE response for gold deposited sample was around $86 \%$ in the spectrum of $400-800 \mathrm{~nm}$ wavelengths. On the other hand, copper, and aluminum showed the EQE response of about $85 \%$ and $83 \%$, respectively. The difference in EQE appeared due to the different work function of the metals as gold having a work function of $(\Phi=$ 5.1) provided the highest $\mathrm{EQE}$ followed by copper and aluminum having work function of, $\Phi=4.7$ and $\Phi=4.1$, respectively. 


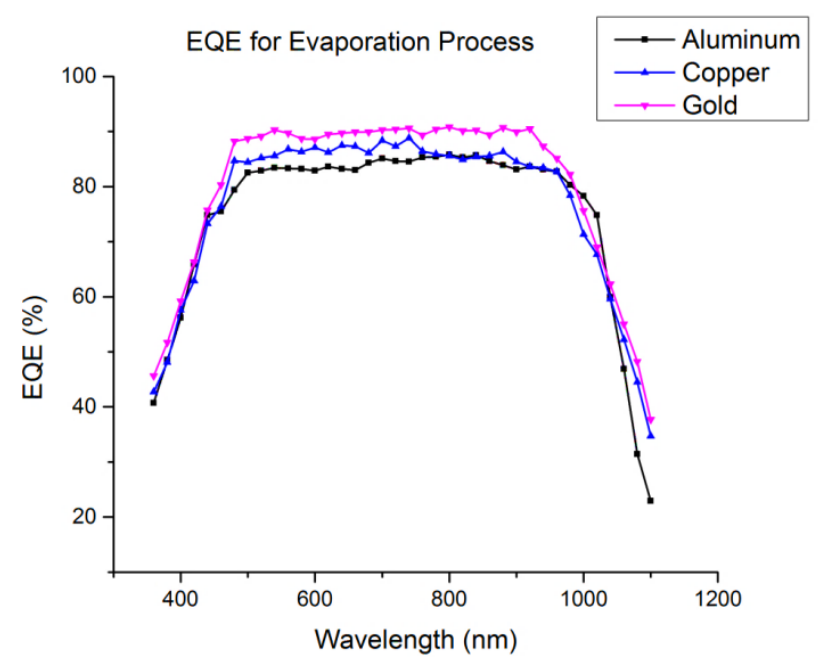

Figure 4. EQE of silicon solar cells with different back contact materials $(\mathrm{Al}, \mathrm{Cu}$, and $\mathrm{Au})$ deposited by thermal evaporation process

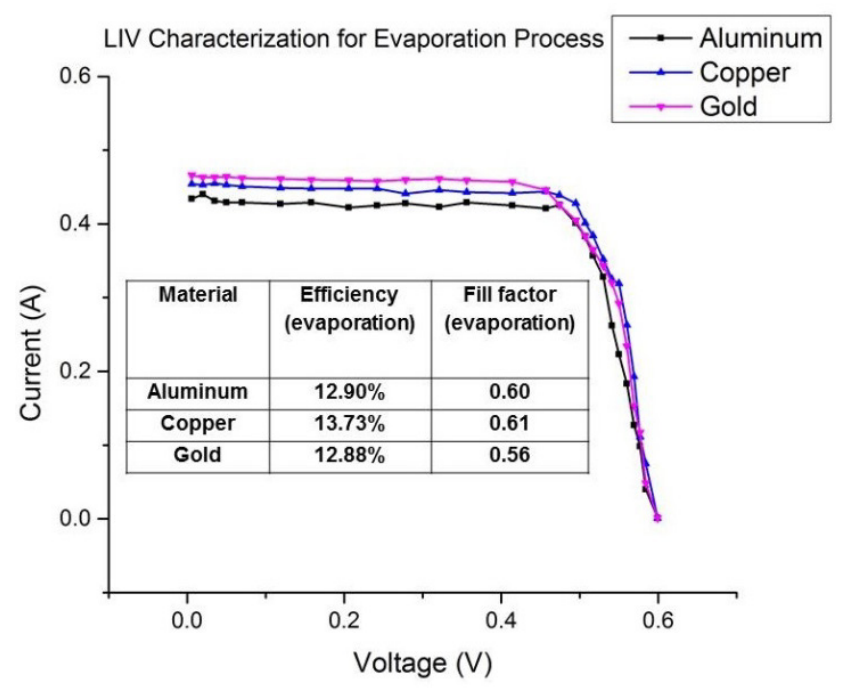

Figure 5. I-V curves with different metals $(\mathrm{Al}, \mathrm{Cu}$, and $\mathrm{Au})$ deposited on back surface of silicon solar cells

The performance of a solar cell depends mainly on three factors which are electron-hole pair (EHP) generation, charge separation due to the built in potential $\left(\mathrm{V}_{\mathrm{bi}}\right)$ and collection of electrons and holes through the respective front and back contacts. The first two phenomena depend on the quality of $p-n$ junction whereas collection of electron and hole relies on the quality of the front and back contacts, respectively. The electron can move easily through the front contact but collection of holes is difficult and depends on the work-function $(\Phi)$ of the back contact materials. Therefore, Fig. 5 illustrates the I-V curves of Si solar cells deposited with different metals on the rear surface using the thermal evaporation process. The short circuit currents measured are $0.46 \mathrm{~A}, 0.45 \mathrm{~A}$, and $0.43 \mathrm{~A}$ for gold, copper, and aluminum, respectively. From the I-V graph it is evident that although gold has the highest short circuit current but the fill factor is comparatively low than the other two metals used and had an efficiency of $12.88 \%$. On the other hand, copper with the highest fill factor obtained the highest efficiency of $13.73 \%$ and the efficiency of $12.90 \%$ was achieved with aluminum as the back contact having, $\mathrm{I}_{\mathrm{SC}}$ of $0.43 \mathrm{~A}$ and $\mathrm{FF}$ of 0.60 , respectively.

Fig. 6 demonstrates the carrier diffusion length and the carrier diffusion lifetime versus the solar cell fabricated with different back contacts. From the figure it is clear that aluminum shows the highest carrier diffusion length of $97.15 \mu \mathrm{m}$ and highest carrier life time of $3.5 \mu \mathrm{s}$, followed by gold having carrier diffusion length of $78.78 \mu \mathrm{m}$ and carrier life time $2.3 \mu$ s. The silicon solar cells prepared using copper as the back contact showed short carrier lifetime compared to aluminum and gold. Hence, from the figure below it can be said that aluminum can be used as a back contact materials for silicon solar cells. In addition to that, because of small carrier life time, use of gold and copper are not suggested as a back contact materials for silicon solar cells.

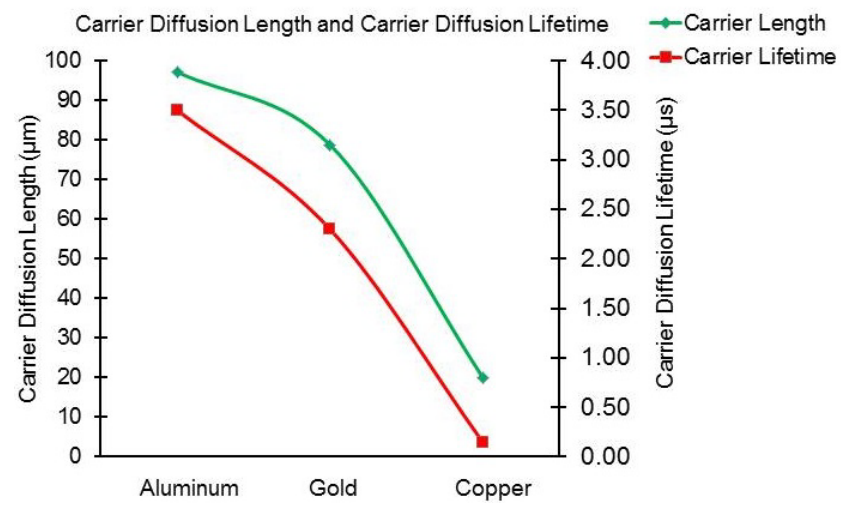

Figure 6. Carrier diffusion length and carrier diffusion lifetime with different back contacts of silicon solar cell

\section{Conclusions}

Metals ( $\mathrm{Al}, \mathrm{Cu}$, and $\mathrm{Au}$ ) of different work-functions have been deposited by thermal evaporation method to passivate the back surface of silicon solar cells. The effects of different passivation are observed in terms of external quantum efficiency, electrical efficiency, fill factor, and carrier diffusion length and lifetime with the different back contact materials. Copper passivated back surface cell exhibits maximum output efficiency of $13.73 \%$. On the other hand, gold exhibits maximum external quantum efficiency $86 \%$, and aluminum showed better performance with the maximum carrier diffusion length of $97.2 \mu \mathrm{m}$ and highest carrier diffusion lifetime of $3.5 \mu \mathrm{s}$. The external quantum efficiency of $83 \%$ and overall cell efficiency of $12.90 \%$ with aluminum based back contact revealed that aluminum is the best material to be used as the back contact of silicon solar cells compared to other metals used in this study. 


\section{REFERENCES}

[1] Kelly Pickerel, Trending in solar panels: Demand growing now, pricing falling later

[2] Jiahe Chen, Recent Developments on Silicon Based Solar Cell Technologies and their Industrial Applications DOI: $10.5772 / 59171$

[3] T. Saga, "Advances in crystalline silicon solar cell technology for industrial mass production," NPG Asia Mater., vol. 2, no. 3, pp. 96-102, 2010.

[4] S. Tobbeche and M. N. Kateb, "Simulation and Optimization of Silicon Solar Cell Back Surface Field," MATERIALS SCIENCE, vol. 21, no. 4, pp. 491-496, 2015.

[5] A. Sinha and S. K. Chattopadhyaya, "Effect of back surface field on photocurrent in a semiconductor junction," Solid State Electron., vol. 21, no. 7, pp. 943-951, 1978.

[6] A. Ebong and Nian Chen, "Metallization of crystalline silicon solar cells: A Review," Conference on High Capacity Optical Networks and Emerging/Enabling Technologies, Istanbul, 2012. DOI: 10.1109/HONET.2012.6421444

[7] S. N. SINGH and G. C. Jain, "Effect of the back-surface field on the open-circuitvoltages of p+-n-n+ AND n+-p-p+ silicon solar cells," Sol. Cells, no. 5, pp. 143-172, 1982.

[8] G. Wehr, I. Zanesco, and A. Moehlecke, "Development and Comparison of $\mathrm{n}+\mathrm{pn}+$ and $\mathrm{n}+\mathrm{pp}+$ Solar Cells in Multicrystalline Silicon," Materials Research, vol. 16, no. 6, pp. 1411-1417, 2013 DOI: $10.1590 / \mathrm{S} 1516-14392013005000138$

[9] S. Dhariwal and A. Kulshreshtha, "Theory of back surface field silicon solar cells," Solid-State Electronics, vol. 24, no. 12, pp. 1161-1165, 1981.

[10] Victor G. Weizer, "The Effect of a Defective BSF Layer on Solar Cell Open Circuit Voltage," Sol. Cells, vol. 14, pp. 241$248,1985$.

[11] J. DEL ALAMO, J. EGUREN and A. LUQUE "Operating Limits of Al-Alloyed High-Low Junctions For BSF Solar Cels," Solid-State Electronics, vol. 24, pp. 415-420, 1981.

[12] J. K. T M Bruton, A Mitchell, L Teale, "Maximising minority carrier lifetime in high efficiency screen printed silicon BSF cells," in 10th European Photovolatic Solar Energy Conference, pp. 667-669.

[13] J. H. Lai, A. Upadhyaya, S. Ramanathan, A. Das, K. Tate, V. Upadhyaya, A. Kapoor, C. W. Chen, and A. Rohatgi, "High-efficiency large-area rear passivated silicon solar cells with local Al-BSF and screen-printed contacts," IEEE J. Photovoltaics, vol. 1, no. 1, pp. 16-21, 2011.

[14] T. Fellmeth, S. MacK, J. Bartsch, D. Erath, U. Jäger, R. Preu, F. Clement, and D. Biro, "20.1\% efficient silicon solar cell with aluminum back surface field," IEEE Electron Device Lett., vol. 32, no. 8, pp. 1101-1103, 2011.

[15] S. Gatz, K. Bothe, J. Müller, T. Dullweber, and R. Brendel, "Analysis of local Al-doped back surface fields for high efficiency screen-printed solar cells," Energy Procedia, vol. 8, pp. 318-323, 2011.

[16] S. Bowden, J. szlufcik F. Duerincks, and J. Nijs, "Rear passivation of thin multicrystalline silicon Solar Cells," Opto-electronics Review, vol. 8(4), pp. 307-310, 2000.

[17] A. Kaminski, B. Vandelle, A. Fave, J. P. Boyeaux, L. Q. Nam, R. Monna, D. Sarti, and A. Laugier, "Aluminium BSF in silicon solar cells," Sol. Energy Mater. Sol. Cells, vol. 72, pp. 373-379, 2002.

[18] J. Zhou, X. Chen, Y. Wang, and B. Zhao, "Influence of glass frits on the formation of back surface field in silicon solar cell," Mater. Lett., vol. 169, pp. 197-199, 2016.

[19] R. Kishore, M. Barbe, J. L. Pastol, M. Caymax, J. E. Bouree, G. Revel, and M. Rodot, "Measurement of minority carrier diffusion length from spectral response of thin film polycrystalline silicon solar cells," Solar Cells, vol. 25, pp. 1$13,1988$.

[20] M. Hörteis, J. Benick, J. Nekarda, A. Richter, R. Preu, S. W. Glunz,"Fundamental Studies on the Front Contact Formation Resulting in a $21 \%$ efficient Silicon Solar Cell with printed rear and Front Contacts," Proceedings of the 35th IEEE PVSC, 2010, USA.

[21] U. Jäger, M. Okanovic, M. Hörteis, A. Grohe, R. Preu, "Selective Emitter by Laser Doping from Phosphosilicate Glass," Proceedings of the 24th EU PVSEC, 2009, Germany.

[22] S. Mack, U. Jäger, A. Wolf, S. Nold, R. Preu, D. Biro, "Simultaneous Front Emitter and Rear Surface Passivation by Thermal Oxidation-An Industrially Feasible Approach to a $19 \%$ Efficient PERC Device," Proceedings of the 25th EU PVSEC, 2010, Valencia, Spain

[23] F. Feldmann, M. Bivour, C. Reichel, M. Hermle and S.W. Glunz, "A passivated rear contact for high efficiency n-type silicon solar cells enabling high $\mathrm{V}_{\mathrm{OC}}$ and $\mathrm{FF}>82 \%$ ", 28th European PV Solar Energy Conference and Exhibition, France, 2013.

[24] Y. Chen, Y. Yang, X. Zhang, G. Xu, J. K. Marmon, Z. Li, Z. Feng, P. J. Verlinden, and H. Shen, "Forming aluminum electrodes by screen printing and electron-beam evaporation for high performance interdigitated back contact solar cells," Solar Energy Materials and Solar Cells, vol. 143, pp. 205-211, 2015.

[25] K.C. Fong, K. Teng, K.R. McIntosh, A.W. Blakers, E. Franklin, N.S. Zin, A. Fell, "Optimisation of $n+$ diffusion and contact size of IBC solar cells," Proceedings of the 28th European Photovoltaic Solar Energy Conference and Exhibition (EU PVSEC), Paris, 2013.

[26] E. Yablonovitch, et al. "Intensity enhancement in textured optical sheets for solar cells," IEEE Transactions on Electron Devivec, Vol. 29(2), pp. 300-305, 1982.

[27] D.H. Macdonald, A. Cuevas, M.J. Kerr, C. Samundsett, D. Ruby, S. Winderbaum, A. Leo, "Texturing industrial multicrystalline silicon solar cells," Solar Energy vol. 76, pp. 277-283, 2004. doi:10.1016/j.solener.2003.08.019 